\title{
Atlantis
}

Critical Studies in Gender, Culture \& Social Justice

Études critiques sur le genre, la culture, et la justice

\section{Out of the Closet and into Quarantine: Stories of Isolation and Teaching}

\section{Michelle Forrest and Phillip Joy}

Volume 42, Number 1, 2021

"Covid and the Academy" \& Open-themed Research

URI: https://id.erudit.org/iderudit/1082014ar

DOI: https://doi.org/10.7202/1082014ar

See table of contents

Publisher(s)

Mount Saint Vincent University

ISSN

1715-0698 (digital)

Explore this journal

Cite this article

Forrest, M. \& Joy, P. (2021). Out of the Closet and into Quarantine: Stories of Isolation and Teaching. Atlantis, 42(1), 31-46. https://doi.org/10.7202/1082014ar
Article abstract

Being queer can be filled with moments of isolation: not fitting in to heteronormative rites of passage, not knowing if or when to come out in academia, and now, trying to cope with the difficulties induced by officially-mandated social distancing in a global pandemic. Although isolation is a common human experience, for queer people it is often an intimate part of their stories, leaving lasting scars. Experiences of isolation, loneliness, and being "othered" have serious consequences. Through autoethnographic queer inquiry, we explore isolation and how it shapes teaching and learning. Drawing on concepts of the outsider-within and the uncanny, and distinguishing isolation from loneliness and solitude, we share our personal stories of isolation through the perspective of a performative "I", examining how our pedagogical philosophies and practices inevitably reflect our queer experiences. Coming from different disciplines of practice, we met because of the COVID-19 pandemic, which prompted this return to old and new forms of social isolation-the old being the experience of growing up queer and the new through teaching online. From our perspectives across a generational divide, we trace the unsettling experiences of being queer and teaching in our COVID bubbles, and we attempt to navigate ourselves and our students safely through disconnection and isolation.
This document is protected by copyright law. Use of the services of Erudit (including reproduction) is subject to its terms and conditions, which can be viewed online.

https://apropos.erudit.org/en/users/policy-on-use/ 


\title{
Out of the Closet and into Quarantine:
}

\section{Stories of Isolation and Teaching}

\author{
by Michelle Forrest and Phillip Joy
}

Michelle Forrest is Professor of Education at Mount Saint Vincent University, a trained actor, and a classical singer. She teaches and writes about the ethics of teaching, collaborative inquiry, feminist pedagogy, and the value of art and philosophy in challenging bias, certainty, and epistemic injustice. Michelle is a career-long supporter of her faculty union, the Canadian Philosophy of Education Society, and the Canadian Association of Foundations of Education. She teaches pre- and in-service teachers courses in contemporary philosophy of education, media studies, open-mindedness in education, aesthetics in education, and research literacy.

Phillip Joy is an assistant professor in the Department of Applied Human Nutrition at Mount Saint Vincent University. He is also a registered dietitian with the Nova Scotia Dietetic Association. He often uses arts-based methodologies for his research that focus on the nutrition, health, and well-being of 2SLGBTQ+ folks. Art can challenge and subvert norms of food, nutrition, sexuality, gender, and bodies contributing to social transformation through the expression of new perspectives.

\begin{abstract}
Being queer can be filled with moments of isolation: not fitting in to heteronormative rites of passage, not knowing if or when to come out in academia, and now, trying to cope with the difficulties induced by officially-mandated social distancing in a global pandemic. Although isolation is a common human experience, for queer people it is often an intimate part of their stories, leaving lasting scars. Experiences of isolation, loneliness, and being "othered" have serious consequences. Through autoethnographic queer inquiry, we explore isolation and how it shapes teaching and learning. Drawing on concepts of the outsider-within and the uncanny, and distinguishing isolation from loneliness and solitude, we share our personal stories of isolation through the perspective of a performative "I", examining how our pedagogical philosophies and practices inevitably reflect our queer experiences. Coming from different disciplines of practice, we met because of the COVID-19 pandemic, which prompted this return to old and new forms of social isolation-the old being the experience of growing up queer and the new through teaching online. From our perspectives across a generational divide, we trace the unsettling experiences of being queer and teaching in our COVID bubbles, and we attempt to navigate ourselves and our students safely through disconnection and isolation.
\end{abstract}

Keywords: COVID-19, performative I, outsider-within, queer inquiry, queer pedagogy, social isolation 
In loneliness, one is abandoned even from that space that was one's own in isolation. By either being abandoned solely to oneself or being dispossessed of even that, isolation and loneliness are social forms of being unmoored in the world.

-Ricco 2020, 165

\section{Introduction}

Social isolation is a common human experience that can be thought of as the absence of meaningful and sustained connections with others (Perone, Ingersoll-Dayton, and Watkins-Dukhie 2020). For many people, the opportunities for meaningful connections with other humans are intimately tied to their identities. For example, identifying within queer communities can shape the experiences of social connections in diverse ways. "Queer" can be used as an umbrella term to represent people who identify outside of socially constructed cis-heteronormative identities, including but not limited to lesbian, gay, bi, trans, pansexual, asexual, and two-spirit identifying individuals. "Queer" has historical connections with abuse, stigma, violence, and harassment of these people within society, as well as the pathologizing of their identities within health care and medical institutions. The term has been reclaimed by these communities in an effort to push back against these historical connotations. It is in this reclaimed form that we use the term "queer," while recognizing the harm that this term has done to many people. Even as "queer" continues to be used in what Youdell $(2010,89)$ calls unsettling and scattering practices, it increasingly functions to interpellate-to make someone or something start to exist or have a particular identity (Cambridge 2021) which puts at risk the term's tactical application of troubling identity spaces. As Sedgwick $(1993,8)$ defines it, queerness is "the open mesh of possibilities, gaps, overlaps, dissonances and resonances, lapses and excesses of meaning when the constituent elements of anyone's gender, of anyone's sexuality aren't made (or can't be made) to signify monolithically."

Social isolation can have serious consequences for the health and well-being of queer identifying people. Some scholars suggest (House 2001; Yang et al. 2018) that social isolation is a "silent killer" by contributing to cognitive decline, heart disease, depression, loneliness, and suicidal ideation. Overall, literature suggests that social isolation decreases the mental and physical health and well- being of individuals (Perone et al. 2020). Building and fostering social connections can be critical to improving health and well-being (Chen and Feeley 2013) and is associated with improved self-esteem in trans and gender diverse individuals (Austin and Goodman 2017). Societal views of queerness shape the experiences of social isolation for many. Some religious views position queerness as unnatural or against a divine being and can lead people to be shunned by their families, peers, and social supports (Lalich \& McLaren 2010). Young people who report a high level of family rejection based on their sexuality are six times more likely to experience depression and eight times more likely to attempt suicide (Salerno et al. 2020).

Within schools, negative views of queerness lead to students being ostracized from their peers and can expose them to violence and harassment. Gender non-conforming students may feel frightened to talk about issues of sexuality and gender to their families, teachers, and school counsellors for fear of being further harassed and rejected, which can lead to isolation and feelings of intense loneliness. It has been noted that, ironically, social isolation for queer youth often occurs in the same spaces, such as schools and families, that are meant to provide meaningful connections and supports (Garcia et al. 2020). Not all teachers are prepared to deal with the complex issues of queer students and there have been recommendations for teachers and advisors within schools to be more effectively trained in this work (Garcia et al. 2020). The fear of family and social rejection, as well as the threat of violence lead many to struggle with the concealment of their identities - another contributing factor to diminished health and well-being (Salerno et al. 2020).

Although queer people face many challenges because of the ways diverse sexualities are often viewed negatively within Canadian society, there are also many supports available. For example, in many school systems across the country Gay-Straight Alliances (GSA) offer social support and safer spaces for queer students (Fetner et al, 2012). GSAs have the capacity to inform and supplement the pedagogical gaps and practices that exclude queer lives and experiences within Canadian schools. ${ }^{1}$ As Lapointe $(2016,206)$ argues, "When educators follow the lead of some GSA members, they may borrow students' queer teaching and learning practices, and apply them within Social Studies classrooms to disrupt the privileging of heterosexuality in schools." Inclusion of queer content within schools can help shift social views 
of diverse sexualities through active participation and disruption of cis-heteronormative assumptions (Lapointe 2016).

The global COVID-19 pandemic that began in early 2020 has intensified the social and health inequalities that queer people face (Fish et al. 2020), including social isolation and social disconnectedness. Many schools and universities closed their physical locations and moved online. For some queer students and teachers, this limited their access to social supports and other queer people (Salerno et al. 2020). The move to online teaching at home also left many queer students sheltered in place with unsupportive families or in situations in which they needed to repress or hide their identities (Fish et al. 2020). As Drabble and Eliason (2021) suggest, the COVID-19 stay-at-home orders and the shutdowns of schools, social support organizations, and queer health service providers may have resulted in queer people being more vulnerable to loneliness and social isolation. Salerno et al. (2020) note that many schools and community-based organizations have moved their support groups, mental health care services, and social activities on-line during the COVID-19 pandemic. Such moves to online formats have been critical for many queer youths and individuals to feel safe to seek support, especially when the platforms used are synchronous and text-based (Fish et al. 2020). Researchers have suggested, however, that many of these programs are at their capacity and overwhelmed by high numbers of people reaching out (Salerno et al. 2020) and there are issues of internet connectivity for many queer people that limit their ability to access these services (Drabble and Eliason 2021).

Finding ourselves facing challenges in our teaching during this pandemic and sharing parallel backgrounds growing up in small-town Nova Scotia, we asked ourselves how we might conceptualize our isolating experiences of teaching and being queer. How might our experiences shed light on the phenomenon of social distancing in terms of what it means for traditionally marginalized folks and for those, like some of our students, who may be experiencing a pervasive sense of loneliness and unease for the first time? Having chosen to analyse the problem of social isolation and loneliness, so prominent in pandemic times, from our perspectives as queer academics, we employ queer inquiry and conceptual analysis to examine four autobiographical accounts of feelings of separateness. These four stories are included in this paper. There is one from each author about a childhood event, and one from each author directly related to the current situation of seclusion precipitated by COVID-19 rules and regulations and our mandated move to online academic work. Using concepts of outsider-within and the uncanny, and distinguishing isolation from loneliness and solitude, we analyse our stories asking how being queer queers teaching and working in post-secondary education in pandemic times.

\section{Queer performative "I"}

We believe that what follows resonates with how Holman Jones and Adams $(2016,197)$ describe the "share[d] conceptual and purposeful affinities" between autoethnography and queer theory. Both frameworks favour fluidity and being responsive to particularities over the assumptions of orthodox methodologies, and inventiveness of methods and theory over static legitimacy. Both take up selves yet resist the notion of stable self-subjects, express how self-subjects are realized in interaction and act in the world, and are political in their commitment to questioning normative discourse and how lives come into being (Holman Jones and Adams 2016).

Like these authors, we use the first-person "I" perspective to tell our stories and to merge our voices through them into a shared experience. Gender-specificity in our memoirs is specific only insofar as it is a common point of resistance. Youdell $(2010,88)$ claims, in reference to ethnographic work, that queer, "whether as a practice, subjectivity or positioning, brings tensions that are productive in their irresolvability." Thus, our interpretations of the following stories are possibilities, not inevitabilities, composed to remain as open as "queer" the category is open and fluid, in order to give a wide range of readers entry for comparison to their own experiences of isolation. As Holman Jones and Adams $(2016,198)$ put it, "My experience-our experience-could be your experience ... could reframe your experience ... could politicize your experience and could motivate, mobilize you, and us, to action." The "performative I" is a concept and technique of storytelling articulated by Pollock (2007, $247)$ to convey what is only possibly real, made real in the writing performance, in order to elude any presumption of a foundational ontology or convenient claims to authenticity. We see this technique as consistent with the contradictory stance of queer inquiry and autoethnography in adopting a subject position in writing while resisting the instantiation of any such position or its experience as stable or fixed. If our stories "work," it is because of their fluidity. As with fiction, their truth lies in 
their verisimilitude or life-likeness, not in their accurate depiction of actual events. Paradoxically, their specificity is what mobilizes an "I" story into your experience.

The difficulty in resisting the notion of stable self-subjects in typical expository writing lies in the authority of the text itself. Once posited, the I (like the we, the you, or the omniscient third-person perspective) is stable and read as such, lending it sovereign rule by virtue of convention. The experienced reader recognizes the positionality elicited by the perspective of the text, accepts it, and reads on without second thought. To say "the self-subject named and implied in this text is not stable" is to make a claim that will be accepted or not, depending upon the strength of the justification given and the reader's inclination to accept it. To demonstrate the potential instability of the writerly voice within the writing itself serves to derange reading as usual by discomposing the reliability of the narrative perspective, thereby evoking the potentialities of an insecure self-subject, and provoking the reader to ask: Why break with convention by disrupting a reliable narrative?

According to Warren (2006, 318), performance ethnography is about "seeing the constructed nature of our lives and then interrupting that seemingly stable process." Using the shifting perspective of the performative I effects this suspension for the reader, who is likely to be confused momentarily about whose voice is whose. As Pollock $(2007,252)$ describes it, the performative I "has a politics and an ethics. Performing displacement by error, intimacy, others, it moves beyond the atomization, alienation, and reproduction of the authorial self toward new points of identification and alliance." In describing how we met and in telling our stories, we inject a politics of instability into the following narrative by not naming clearly each self-subject in turn, as a means of implying the ethical question regarding the value of irresolvability in response to the particularities of queer lives. Thus, our experience "could politicize your experience and could motivate, mobilize you, and us, to action" (Holman Jones and Adams 2016, 198).

\section{"Twice-told Tales"2}

Phillip and I are colleagues at the same small university; he is a new hire and I have been here for twenty years. Under normal circumstances, before campus restrictions due to the pandemic and our move to online work, we likely would have met at the annual union event to welcome new faculty. It was COVID-19 and our shared in- terests that brought us together professionally because the university art gallery moved their weekend workshops online. In November 2020 we both signed up for one on queer memoir comics. ${ }^{3}$ Before the pandemic I was commuting two hours to work and back, so, oncampus weekend art workshops were more than I could manage.

Drawing comics has always been a love of mine, inspired by my father's facility for reproducing comic strip figures from the funny papers. My early experience of formal art training thwarted that interest because, in those days, comics were not considered art. I often add cartoon-like characters on notes or cards to friends, and I teach a graduate seminar on aesthetics in which we engage in various art activities and I have written about the provocative role of non-traditional art forms in teaching to be critical (Forrest 2001). The workshop rekindled my childhood love of these cartoon drawings, got me thinking about being a queer feminist teacher and philosopher of education, and offered another way of bringing art, life, and professional practice together in my course for in-service teachers.

Like Michelle, my interest in comics was born in early childhood, along with my love of fantasy and science-fiction stories of heroes battling the forces of evil. In my work in Applied Human Nutrition, I do arts-based research using comics to study body image. My research reveals that representing the lived experiences of queer men and their bodies through comics can be a positive, self-reflective experience (Joy et al. 2020). I was looking for ways to further my use of comic art in my research, which brought me to the workshop. So, there we were, meeting for the first time, in a setting that foregrounded sexual orientation and memoir, and that experience prompted us to work together across our respective fields of Education and Applied Human Nutrition to consider what our past and present experiences as queer scholars and teachers negotiating the challenges of COVID-19 might have to offer readers of this special section of $A t$ lantis.

In her December 2020 President's Message to unionized university faculty in Canada, Brenda Austin-Smith (2020) describes what we have been living:

We can all by now list a ton of words and phrases we are sick and tired of hearing from administrations to describe our collective scramble to adjust to the COVID world. We have pivoted and relaunched; we have over- 
hauled and uploaded; we have weighed the merits of synchronous and non-synchronous instruction. With a variety of makeshift home studios set up across the country, cameras and laptops perched on top of books and cartons and counters, we have all become broadcasters. But the most irritating phrase from the past term for me remains "We're all in this together." Because we are not. The virus may be global, but its effects are systemically uneven in our sector, as in many others.

Austin-Smith rightly goes on to point out how much worse the effects of the pandemic have been on academic workers in precarious, part-time contract positions. Mandating that university programming go online has meant the prospect of lost revenues from empty residences, among other things, and increasing class numbers to mitigate budget shortfalls has led to lost employment for many part-timers teaching in Canadian universities (Wright et al. 2020). Those of us fortunate enough to be tenured or in tenure-track positions are a privileged minority. The challenges we face and present in this paper are not as extreme as those experienced by many of our contracted colleagues. We have secure full-time jobs and institutional support to represent our experiences. Wherever our stories figure in the larger picture of pandemic-related stresses and anxieties in the academic workforce, they do open a window on life in post-secondary teaching and research under these novel circumstances and, as such, may shed some light on the plight of those worse off than us.

\section{Tempting Fate}

It was time for the annual school play and my grade 5 teacher decided that our grade would portray an assortment of "walks of life." I don't remember having any choice in the matter but recall vividly not being thrilled with her choice for me. I was to depict a "wife" and would wear a wedding dress. I wasn't privy to whatever the adults may have decided. What Sister Mary Anthony-I call her that to protect the late woman's identity-may have asked or told my mother remains unknown. All I remember is being taken off to my aunt's place where she opened her cedar chest and offered up her own wedding gown for me to wear in the play. My mother was older than my aunt and had been married in a smart suit, Rita Hayworth style, after the war when times were tough and ordinary folks didn't splurge on single-occasion wedding apparel they could not afford. So, out of moth balls and tissue paper came my aunt's lacy gown and veil to be worn by me, likely after some alterations.
Those were the days when what the teacher said held unquestioned authority. So, if my mother and aunt considered not complying with Sister's wish, it never came up. Perhaps it was the availability of the yellowing wedding dress that landed me the role. I shall never know since it was only thinking about times of isolation that brought this absurd and humiliating episode to mind again. What I do remember clearly, as if it were yesterday, is feeling an absolute fool and knowing, without ever having been taught such a lesson, that there was something strangely ominous about wearing a wedding dress for anything other than one's own marriage service. I felt too conscious of tempting fate to play act such a serious event. I may as well have been playing the corpse at an enactment of my own funeral. These were solemn ceremonies, this I knew well, going to a parish school and being taught in religion class that they were sacraments. So, why couldn't I be the nurse, or the teacher, or the secretary? I don't remember anyone making fun of me, though the dress didn't fit all that well. My classmates all seemed pleased with the grown-up roles they were playing. I felt ridiculous and completely alone in my discomfort. Standing on that stage, reading the lines I'd memorized about the role of wife and mother, I had an odd sense of foreboding, as the stays in the bodice stuck into my ribs and the scratchy veil made my head itch.

The experience related in this story made me feel queer, in the root sense of strange, odd, or peculiar. Deep down I knew something was not right about it, yet all the adults seemed to think it perfectly fine. I may have complained to my mother about the feel of the dress and that veil, but not about my worry that something more was amiss, because I had no language to express it, even if I did have the nerve to object to the play and my teacher's wishes.

The etymology of the word queer is uncertain, though it is suspected to have come from the German quer meaning transverse, oblique, crosswise, obstructive (of things going wrong) (Oxford 2021). I had the feeling that by wearing that wedding gown I was asking for things to go sideways in my life, which they did subtly and incrementally without my acknowledging to anyone, including myself, that I was destined never to live the cis-heteronormative life I play-acted on stage that day.

According to Youdell $(2010,89)$, "We have no grip on queer." Understanding this was not a rhetorical or conceptual possibility for my ten-year-old self at a time when the term "queer" had not yet been reclaimed as an ironic badge of honour among those on the periphery of 
heteronormativity. ${ }^{4} \mathrm{I}$ had no language for what felt strange and alienating up on that stage or for why I felt a sense of foreboding being typecast as a bride at age ten. Now, that episode seems emblematic of my isolation, in a time and place when being queer was best kept secret. Viewing myself as someone playing a part in a life I was destined to watch from a distance, I could not have known then how long it would take me to recognize and acknowledge why playing that role felt so strange. In Black Feminist Thought, Collins (2009/2000) describes the experience of feeling nothing wrong in being who she was in a world where "apparently many others did." As she grew up and that world expanded, she felt herself growing smaller. "I tried to disappear into myself" is how she depicts the childhood experience she later describes as "being placed in a curious outsider-within social location, a peculiar marginality that stimulated a distinctive Black women's perspective on a variety of themes" (Collins 2009/2000, vii, 13). ${ }^{5}$ Being queer in a cis-heteronormative society, even though I had no name for it, made me internalize a similar outsider location which gender diverse persons occupied back then and still do in many ways today, despite protections in Canadian law and tacit social acceptance.

\section{Hours in a Library ${ }^{6}$}

I looked down at my fingers and stared at my nails. They were well-kept, clean with no dirt buried within them, but long, for a boy. I thought they were pretty. They made me feel like one of the rich and beautiful stars on Beverley Hills 90210. But in this moment, as I examined each nail in turn, I began to feel panic. Icy tendrils of dread reached out from the pit of my stomach to diffuse through my whole being. It was by now a familiar sensation. It was the sensation of my junior high school.

This day I was in the library, with its fluorescent lights humming ever so slightly. When you first entered there was a central open area with a help desk where there would sometimes be a teacher. Off to the right there were long wooden tables. To the left, grey metallic bookcases in neat rows. The back wall was divided into cubicles with windows that overlooked the back of the school, the baseball field, and a row of orange school buses waiting for the end of the day. The library had become a hideaway for me. Earlier in the term, the guidance counsellor of the school had suggested it as such a place. A place I could go before the morning bell rang to avoid the awkwardness of walking the hallways alone, a place I could go during recess to avoid the name-calling, and during lunch to avoid the bullies who threatened me with violence. I was grateful for his suggestion.

Today, however, the library did not offer its usual shelter. In the last ten minutes, the library had turned from my sanctuary to my prison, invaded by the boys that I tried so hard to avoid. I was in the stacks, nestled as far away from the door and the outside world as I could get. I was in my own personal cubicle, or what I had claimed as my own, and the newly arrived boys were in the front of the library, settling down at one of the tables. There was no way out without being noticed. One of them was Kester, a dark-haired boy in the same grade as me. He was an avid reader so his presence in the library was not a surprise and I assumed he was in the library for a book. He left the others and entered the stacks. I had known Kester since we were five; we started school together, celebrated birthdays together, and went to this new junior high school together. It was only in the last year that he became one of my bullies.

I prayed that he would not notice me as I slid further down in my chair. But fate had other plans. He came over, his intent obvious in cocky stride and the smile he wore. He leaned over the wooden divider of the cubical about to say something I could only imagine would be mean. But before he did, he must have noticed my hands on my book. My nails had caught his attention. He demanded to know why they were so long. Didn't I know that boys were not allowed to have long nails. Didn't I know that only girls were allowed that privilege. Why was I so weird? he asked, without hesitation. He stood there waiting for me to say something. When I could not answer, he hurried off to his friends to report my transgressions to them. Time was running out. Kester would be back with the other boys soon. I looked at my nails and started biting them down.

This story reminds me that times spent in the library were safe times away from the destructive setting of my high school-an experience that is true for many queer students. The staff were helpful in providing the advice to seek shelter from the bullies in the safe space of the library, but they were also complacent in upholding the strict hetero- and cis-normative learning environments that created and perpetuated my terror. The repercussions of those terrifying moments are still visible on me, symbols of my queerness. They run along my body, rivers of shame that transform the way I interact with others, friends, colleagues, and students. I often wonder how I would be different if I had not felt so alone and fearful of the other students. What if my teachers had suspected that my soul was inflicted with loneliness and 
what if they had been more willing to step in? How could they have continued to ignore my silent cries as other students circled and threatened me with violence in the hallways? Surely the teachers were not that unaware of these occurrences? They should have tried to question and disrupt the normative discourse of gender. After all, why should I have needed the library as my own secret safe space? Should not the whole school have been safe for me?

As I reflect on my queer transformations and my own teaching I cannot help but question how these experiences shape my own classrooms. Do I now ignore the cries of hardship and isolation in the virtual hallways of my classroom during the global pandemic? Have I, as Freire $(1974 / 1968,23)$ warned, become one of those who oppress? Another cog on the "circles of certainty" in a dehumanizing, traditional education system that has simply been transposed on-line to address the realities of COVID-19?

I try to be compassionate to my students, especially teaching through the global pandemic. I offer extended deadlines on all assignments, give my students twentyfour hours to write all their exams, and try to create as many classroom connections as I can. I attempt to recognize the many difficulties they may be dealing with struggling to learn in virtual isolation during this global pandemic. Unlike Freire's radical sectarian, I do not "suffer from an absence of doubt" (1974/1968), but, I ask myself are current conditions calling me to implement more radical change? Although my students' struggles may be different from those of folks growing up queer and alone, I try to imagine myself as the helpful and caring teacher I needed when I was a student hiding in the library. How can I draw from that formative experience of fear and isolation to help us cope with the pedagogical transpositions we are now experiencing?

According to Sedgwick (1993, 4), 'queer' is a politically potent term because, "far from being capable of being detached from the childhood scene of shame, it cleaves to that scene as a near-inexhaustible source of transformational energy." Those carefully manicured nails that I loved became marked by "shame's threshold between sociability and introversion" (Sedgwick 1993,12). Has this history of negotiating queer instituted for me "far more durable, structural changes in [my] relational and interpretive strategies toward both self and others" (Sedgwick 1993,13)? If so, how can I draw from this source of strength to enact the queer pedagogy Britzman (1998,
82) describes as "constituting normalcy as a conceptual order that refuses to imagine the very possibility of the other precisely because the production of otherness as an outside is central to its own self-recognition." This is not a search for the 'correct' method or 'right' questions; but rather, like queer inquiry, it is a pedagogy that "works to question situations of apparent normality in the classroom and concerns itself with the social production of what is learned" (Neto 2018, 256).

How we have established our professional identities directly affects the assumptions we bring to our relations with students, beginning as we do from positions of vulnerability that carry "transformational energy" earned on the "threshold of shame" (Sedgwick 1993, 15). This shapes queer identity as "to-be-constituted," rather than giving that "identity-space" the standing of an essence (Sedgwick 1993). As Britzman (1995, 153) points out, 'the 'queer,' like the 'theory,' in Queer Theory does not depend on the identity of the theorist or the one who engages with it." The extent to which we as teachers disclose our queerness in the classroom is not pivotal in our orientation to queer pedagogy. What makes our pedagogy queer is how we balance resisting the normalization of education and the taken-for-granted givenness of standardized curricula with accepting the challenge of "proliferating identities; not closing them down" (Britzman 1995, 158).

DePalma $(2020,6)$ asks if queer can be purposeful and suggests five directions one can explore in conceptualizing queer pedagogy: unsettling and unlinking hierarchical binaries; analysing processes of normalization; privileging embodied experience over preconceived knowledge; critically analysing media tropes and images to uncover the hidden curriculum of popular culture and everyday learning; and, working within and against institutionalized schooling (DePalma 2020, 9-10). In these suggestions, we recognize what makes our pedagogical orientation queer. Central to our pedagogical aims has been bringing a critical lens to teaching dietetics and education by troubling distinctions between dominant inter-related concepts such as wellness and illness, care and competence, queer and straight. This work is inextricable from our larger analyses of normalization in health care and teaching, such as, how success is increasingly evaluated more according to statistical metrics and less on the nuanced qualities of human relations that justify our disciplines as caregiving professions. We raise questions in our classes regarding the systemic epistemic injustices perpetrated upon vulnerable bodies dependent 
on public institutions, such as hospitals and schools, ostensibly dedicated to support them; questions about the ethics of care, cultural sensitivity, and what it takes to debunk tired stereotypes and comfortable certainties. We came together on account of our keen interest in analysing oppressive biases in mass-media imagery, such as those both reinforced and challenged in popular culture and that affect deep-seated assumptions within the public imaginary. Each of us works within and against the dominant normalizing tendencies of our disciplines of practice, even as we teach their protocols to aspiring professionals.

Working together in socially-distanced isolation from our departmental colleagues and students during this pandemic has brought into sharp relief what Britzman $(1995,152)$ describes as the "centripetal force, of a cultural insistence to put back into place boundaries at all costs, that education is obligated to exceed." By questioning situations of apparent normality and enacting concern for the social production of what is learned, purposeful queer pedagogy has the potential to generate new relational and interpretive strategies between teacher and student. The precipitous pivot to online teaching has provoked unexpected social and learning conditions the effects of which are only beginning to make sense to those of us thrown into this massive educational experiment that has been implemented with no prior risk-reward ethical analysis.

\section{Unmasked}

It's the pandemic spring of 2020, the prime minister has called for a nationwide lockdown, universities have moved to virtual teaching, and I am about to start my first online course, an experience I would never have chosen willingly. I have had three weeks to get a course I'd developed and taught several times ready for this new-to-me mode of delivery. The idea of "course delivery" is one I'd always avoided since it evokes Freire's (1974/1968) banking metaphor critique of education. Deposit/deliver content in hopes it earns interest, like putting money in a bank account. People are not empty accounts to be filled or blank slates waiting to be written on. Yet, despite Freire's influential critique, the language and rhetoric of the knowledge economy imposes its epistemological assumptions on post-secondary education, now magnified as COVID finds us all scurrying to shelter from face-to-face contact and implement new ways of teaching.

Deciding on a place in the house for my home office means not monopolizing any room that may otherwise be needed as I spend hours online each day. At first I assume the headset will help cut me off from my environment and protect my partner from having to hear the workings of all my meetings and classes. Quickly I discover it hurts my ear and gives me a headache; so, the laundry room in the basement becomes my work hide-away. I try to angle the computer so it does not give pride of place in the background to the washer and dryer, but glare from the window makes that difficult. When wash-day coincides with class or meeting times, I push the rack full of drying clothes to the far corner of the room, away from the camera's prying eye. On the wall behind me is a large framed photo of me on Brighton pier, all those years ago when I thought my future would be in the performing arts. Little did I know that one day my stage would be this "philosopher's laundry."

The course is a graduate seminar of twenty-more students than I can comfortably get to know and draw out in discussion in this awkward format. We communicate mainly by speaking and listening, as on a radio talk-show, with the occasional talking head appearing on screen; me welcoming students or bidding them adieu, leading discussion, or answering general questions; and students, at most two at a time, sharing their work. We must save bandwidth, we are told, by being judicious in our use of this digital platform. All the while, random running comments from students pop up in chat balloons that disappear before I can read them if I don't have the full chat thread open, stage right. My teacher voice tends to be most prominent, framing each class with intros and wrap-ups, leading into group work, answering questions, and directing most discussions. Some students take up my invitation to put a photo up in place of the default silhouette avatar; many do not and so, in most instances, voice recognition is how I tell students apart. Those who immediately stand out are two with deeper, male-sounding voices and two of the eighteen female-sounding voices whose first language does not seem to be English. The other sixteen female-sounding voices, all with similar turns of phrase and intonation patterns, are difficult to tell apart, especially for the first few classes. This adds an awkward note since I have to continually look for the open microphone symbol on the class list to be sure I'm calling them by their correct names. Calling each student by name is part of an ethics of care in teaching, which seems all the more important in this de-personalized classroom.

After my first online class, I am pleased that things went fairly smoothly, without any technical hiccups, but I feel uneasy. One student tended to dominate the small and large-group discussions. Since this is early days I put it down 
to students' reticence to speak in the first meeting, especially while distanced from one another. It becomes clear by the end of next class that my initial unease was well-founded. The same student takes up more air-time than he ought to and is very opinionated, taking issue with everything everyone else says. To fairly distribute air-time and in hopes of taking the wind out of his sails, I impose time limits for responses and curate discussions more closely than I prefer doing in a grad seminar. This does the trick but being on guard against his oppositional demeanour threatening to direct the flow of conversation keeps me on edge and I am pleased when the course is over. What the other students thought of the experience is anyone's guess. On account of COVID, the anonymous student ratings of instructors are made optional and, with all the other challenges in my altered work life, requesting that students be sent evaluation forms is just one more thing I don't have time to think about.

It seems that whatever chance I might have had of developing the relaxed style I try to arrive at in-person with students is compromised by the student who loves to hear himself talk, and by whatever is at the core of the uneasy feeling his behaviour evokes in me. Why does he get to me so much? After years of teaching high school before moving to post-secondary, why should something so simple have this effect? Might things be different on campus where I could gange everyone's responses to his adversarial tone? Having a group of relative strangers peering into my home through a webcam feels invasive. Years of theatre training and teaching hasn't prepared me for this experience of intimate, exposed isolation.

Looking back on that first experience of teaching online has allowed me to see how I was strangely unnerved by one student's tone and the relational dynamic he provoked. At the time, his interactions made me question what I might have done differently. My tacit intention from the start of the course was to try and produce a learning environment as close to an in-person or normal classroom as I could. On later reflection, I wondered if I had deceived myself by assuming that any approximation of apparent normality was possible under these conditions or, indeed, ever? The pandemic brought to the fore the social production of what is learned and the instability of my assumptions about what constitutes normal. How I interact as teacher with students is as integral to what is learned as is the subject matter I choose for the course syllabus. I know this to be true from years of educational philosophy and curriculum theory, ${ }^{7}$ and yet, these new circumstances led me to miss the obvious. The pre-planning required for uploading course materials onto a digital platform took my focus away from the social production of learning as lived and directed it towards a digital production line of pre-determined discrete files and documents. Filling up the online course site gave me a false sense that the course could somehow teach itself. It looked so impressive with links and layers of PDFs, URLs, assignment drop-boxes, video streams, and other dazzling, digital accoutrements. All it took was one oppositional student to evoke the unease of my latent outsider-within. The unreconciled contradiction between who I know myself to be and the objectified other that queerness consigns me to is always already at play in every human relation, ready to undermine any presumption I make to being "normal" or teaching "normally."

Attending the queer memoir comics workshop where Phillip and I met is what got me thinking about growing up queer but unaware of what it was that made me feel different. I put it down to being an only child; I was the only "only" I knew and assumed that not having siblings to relate to was what made me feel distanced from even my closest friends. As I matured, nothing remotely resembling gay pride was part of my cultural milieu, even though my under-graduate years coincided with the Stonewall Uprising that sparked the global movement for gay and lesbian rights. ${ }^{8}$ Although wearing that wedding dress felt wrong, I put it down to tempting fate, nothing more. All these years later, though my partner and I have been together for over thirty years and LGBTQ+ pride has been a phenomenon I respect and discuss in my teacher-education classroom, I never took the movement to heart personally until I began to discuss queer theory with my gifted new colleague. This experience helped me realize my complicity in permitting cis-heteronormative impingements to linger in my life and work. As a feminist, I had not paid sufficient attention to queer theory nor brought it to bear more directly on my own attitudes, past and present. In her autobiography, Rosemary Brown (1989, 81) describes reading Betty Friedan (1963) and experiencing that click of recognition whereby she realized she had more in common with other women than what divided her from them. In the uncanny discomfort I felt when being challenged by that obstructionist student during COVID online teaching, I experienced more of a thud than a click of queer consciousness-raising. Thankfully, I finally faced my long-standing capacity to reinterpret my queerness in ways that fit within mainstream stereotypes of resistance, such as assuming that philosophical training inevitably 
made me critically astute and aware of contradictions. How ironic that in so assuming I was performing yet another contradiction.

Britzman (1998) contends that the "force of secrets" effects "the need to excavate the lost subjects of education until what is uncanny can be engaged" $(1998,13,15)$. Youdell (2010) points out that the Freudian concepts of the uncanny (unheimlich) and its opposite, the homely and familiar (heimlich), are implicated in each other. "[T]he uncanny is at once what is homely and familiar and what is hidden" (Youdell 2010, 91). According to Freud, the uncanny has an unsettling effect because it "leads back to what is known of old and long familiar" and this return entails ambivalence and ambiguity. As Youdell explains, "Not only does the uncanny speak of an ambivalence of feeling and meaning, but the relationship between the unheimlich and heimlich is itself ambiguous, with what is heimlich also coming to mean the familiar re-emerging in a place it should not be-the unheimlich" $(2010,91)$. Under COVID-19 restrictions, the familiar is systematically defamiliarized or made uncanny: ${ }^{9}$ teacher-student relationships; daily faculty/staff interactions; scholarly/professional society meetings; human-science research practices; domestic arrangements for families and communities. This is a world turned sideways with everyone continually holding the familiar up against the unfamiliar that, we hope, will soon recede. This is not a situation in which old ways can be abandoned and new ways embraced; rather, we work in familiar and unfamiliar conditions simultaneously. Queer folks who carry the "force of secrets," regardless how seemingly resigned, reconciled, or oblivious they are to this fate, may see the pandemic as both an opportunity to "excavate the lost subjects" of their education and engage with the uncanny, as we are doing here in our stories. By examining our ambivalent feelings about these shifts in working relationships and the contradictory meanings we draw from them, and by learning to live and work in the ambiguity of finding strength from our own vulnerabilities we lead ourselves into new unknowns, in the light of what is old and familiar.

\section{Fifty COVID Bubbles}

It was my first time teaching online. I had three courses in this term of COVID-19 online teaching. The term was almost over, and I had just finished reviewing the last assignment for one of my classes. This class was a first-year course with about fifty students. I looked around my office. In August, I had transformed my spare bedroom into my new teaching, research, and office space. I spent several hours rearranging the room, putting pictures on the wall that made me smile and tinkering with the small corner of the room that would be visible to my students through my webcam. I did not relish the idea of the close-up images of my face bobbing back and forth on their screens, but I wanted the background to be fun and joyful. The thought of removing the "gay" stuff - the rainbow flag, the RuPaul merch, ${ }^{10}$ the pride teddy bear, the movie stills from the Wizard of $\mathrm{Oz}$ had briefly flashed across my mind like lightning in a storm. A quick mental argument ensued: this stuff reflects me so why should I hide it? The days of hiding myself were past. The pit of my stomach was heavy-it was those feelings of fear, those feelings of not being accepted. The mental cartwheels continued. Ignore that feeling. I want to be a 'good' instructor to these students and to do that I need to be myself. Afterall, I intended to create safer spaces through the displays of pride items, such as the rainbow flag. Besides, my office on campus would be similarly decorated. Pride symbols are important for those students who may be looking for signs of acceptance. I know I would have felt less isolated in the library if my teachers displayed the rainbow. Although I may feel unsure or fearful of displaying such symbols, it is important for both my queer pedagogy and for being myself. I made my decision to leave the gay stuff where it was. The voice in my head always has to have the last word: "But what happens if these pieces of yourself are not accepted?"

This work I had just finished looking over was a visual assignment in which I asked students to include photographs. I was not expecting them to include selfies, but I was pleasantly surprised when a few of them did. It actually took me off-guard and felt very surreal. To be honest, throughout the term sometimes it felt like speaking into a void. I knew the students were there. I could see their names. They would type in the chat box questions they had or the responses to my questions, but very rarely would they use their microphones. I think I can count on my fingers the actual number of students I heard speak. Even more rare was the use of their cameras. Many did not even have a photo in their profile.

I think this was the source of my recurring feelings of being in a virtual void over the semester. It was not the students' fault nor was it mine. I recognized that. There was nobody to blame. The pandemic was raging across the globe and this was one of its many consequences. But I did try to minimize the void. I tried everything I could think of to more fully engage the students and to create those much-needed connections. I used online break-out groups to get students 
to connect and encouraged them to use their microphones and cameras within their groups and in the class generally. I felt like a bit of a rebel doing that since we received institutional recommendations to discourage students from using their video, to save bandwidth and preserve connectivity, but was it pedagogically sound? I would debate that.

I would often jump virtually between break-out groups whenever I used them. Each time I entered a new room it felt like an intrusion. I felt like there should have been a knocker to announce my entrance to the group, like the computer voice from Star Trek replaying a standard message, "Warning. The professor is now entering the room." It sometimes felt like there were fifty different worlds, each one a bubble unto itself and, in a way, there were: fifty pandemic bubbles floating in the digital classroom. I think this was why I was so pleasantly surprised now. Seeing the students' selfies in their assignments was uplifting. It was December and the first time I was seeing the faces of some of my students. In many ways, teaching during a global pandemic was a lonely craft.

The word "bubbles" conjures up so many thoughts in my mind lately. Translucent and shimmering orbs floating through the air or the image of Glinda the Good Witch travelling through the Land of $\mathrm{Oz}$ inside her own little bubble (Baum 2010/1900). Since the onset of the COVID-19 pandemic, the word has taken on new meaning. Personal bubbles, household bubbles, and even provincial bubbles popped into existence as the infections spread across the country. ${ }^{11}$ According to Danon et al. (2021), bubbles, in reference to COVID-19, are defined as "small, non-overlapping, groups of households that are permitted to come into contact with each other ... intended to maintain benefits of social distancing while reducing the negative impacts of isolation." From July 2020 to now, I am within my teaching bubble, isolated from my students, my colleagues, and my university community for the benefits of social distancing. As a mostly shy introvert, I did not mind this too much, but the teacher in me, who is more extroverted, has struggled to create meaningful connections with students through virtual classrooms. The challenge is epistemic and existential, as I question the grounds of what I thought I knew, adjusting to new insight, providing authoritative stability for students cut off from a campus community, even as I question who I am as a teacher and academic.

Writing these memories of isolation-a queer youth in the library and an early-career scholar in his COVID teaching bubble-has helped me draw connections between them, connections of spatially, of physicality, and of emotions. The library, although a safe haven for me in troubled times, was a haven for one. It was a physical separation from other humans. The office I used for my online teaching was also separated from others, another space for one, a familiar part of my home turned theatre set for vicarious viewers. Although other people were within the library and although my students were present in my online classroom, little sense of them permeated my senses. Absent were the coughs, movement of chairs, and whispered remarks typical of in-person teaching. These memories are uncannily the same and yet different.

Yalom distinguishes three types of isolation and loneliness: intrapersonal, existential, and interpersonal (1980, 355). The global pandemic puts queer folks at risk of loneliness and anxiety from all three. Internalizing an outsider-within as a result of growing up queer can cause intrapersonal isolation from oneself, reflecting this dissociation and precipitating feelings of loneliness, especially in presumptively cis-heteronormative social situations. Existential isolation is one of life's givens; for everyone there is an "unbridgeable gulf" between the self and another (Yalom 1980). And, with the social distancing mandated by COVID-19, interpersonal isolation can exacerbate the other two conditions, magnifying the endemic loneliness of a queer life pre-pandemic. Fear of existential isolation, typically present in the face of imminent death-a reality COVID-19 has brought closer in fact and in the public imaginary-raises defenses that can cause numerous interpersonal issues (Yalom and Josselson 2014). In a cis-heteronormative society, queer folks feel lonelier and less socially embedded, particularly when they feel the need to censor their identities in interpersonal relationships, all of which makes it more difficult for them to find others who share their vision of existential loneliness (Ratanashevorn and Brown 2021). Assuming mass vaccinations are successful in producing herd immunity, COVID bubbles will burst and semblances of pre-pandemic societal relations will resume. Queer pods of isolation will persist as before.

\section{Conclusion}

Ricco suggests that, in addition to the bio-political (life preserving) and the political-economic (work/profit focus) responses to the COVID-19 pandemic, there is something beyond these dominant perspectives that is "more ominous because it is more fundamental" 
$(2020,165)$. The space of separation between people, or "zone of ethical sociality," is no longer "left open, in-appropriable, and to be decided," which erodes our freedom in more than a physical sense. The phrase "social distancing" is therefore an oxymoron because the distance between us is always "the very spacing that structures any sense of the social." Isolation evacuates that space such that each of us is "abandoned to a mine-ness that is lacking betweenness," a condition that can evoke feelings of loneliness and "being unmoored in the world". Without being tethered by the shared space of sociality, the structures of decision and the ethical are fundamentally compromised (Ricco 2020). Ricco (2020, 165) draws on Arendt's $(1973 / 1951,476)$ distinction between loneliness and solitude in which the latter is a necessary condition of dialogue with the self that only results in loneliness if "all by myself I am deserted by my own self." Arendt issues a dire warning: "Loneliness and the logico-ideological deducing the worst that comes from it represent an anti-social situation and harbour a principle destructive for all human living-together." This picture is not without hope, however. Ricco describes how pandemic isolation has had positive effects. Many have found recourse in "artistic practice, writing, craftsmanship and other modes of making and fabricating that benefit from being left to one's creative potential" (Ricco 2020,166). And, as Arendt states, it is only when the elementary form of human creativity that allows each person to "add something of one's own to the common world" is disrupted that isolation becomes unbearable (1973/1951, 475).

Sharing our stories of growing up and teaching "queer," we contribute to what Spry (2016) calls the "politics of 'I', which enact the potential of performative autoethnography to embody "epistemic discomfort in an effort to explore why it exists." She considers performative-I epistemology to be empathetic, keeping her looking "forward and back to my own dis-ease" (Spry 2016, 30). Coming together by chance and discovering how much we share across generations and disciplines in the same workplace-even though we have never met in personhas given us the grace to describe our difficulties in a world thrown sideways, and to examine our dis-ease at being expected to be "expert" in a pandemic context of apparent education-as-usual. Performing familiar roles with scripts we did not devise but must enact nonetheless has evoked in us the uncanny, a return to that which is familiar but continually made strange and unsettling. Citing Pollock (1998), Spry says that performative writing encourages her to "move into a space of practiced vulnerability with her own work" (2016). Attempting to come to terms with the effects of our epistemic discomfort on our pedagogical and scholarly practices has elicited old and queerly familiar vulnerabilities that we are grateful to be able to share. Continually, we wonder how best to leverage the precarity of our experiences to help our students.

We have presented our stories of being queer faculty during the global COVID-19 pandemic and, from a performative "I" perspective that unsettles the reader, we have described how being marginalized growing up queer surrounded by cis-heteronormative social structures and norms still evokes our outsider-within and consequent feelings of the uncanny. Unfortunately, for many queer folks, these are all too common experiences, leading to social isolation and disconnectedness. Through this collaborative queer inquiry we have come to realize more acutely how our experiences of marginalization have shaped our philosophies of teaching and been magnified, as seen through the prism of our COVID bubbles. Although our students may not have internalized the isolation of living a queer life, pandemic isolation challenges and invites each of us to draw on our creative potential to add something of our own to the common world. The time is rife to "share conceptual and purposeful affinities" between our personal narratives and queer inquiries (Holman and James 2016, 197), and in so doing to look into "the truth that every end in history necessarily contains a new beginning" (Arendt 1973/1951, 478).

\section{Endnotes}

1. In Halifax Nova Scotia, two school counsellors began the Metro Teachers Gay Straight Alliance to support LGBTQ+ teachers who may not feel safe disclosing their identities within the school setting, despite the fact that things have improved for LGBTQ+ students. See Blinn and McKay, 2020.

2. Nathaniel Hawthorne used Shakespeare's phrase "twice-told tales" to name a collection of his stories, some of which had been told before. We use it in that sense and also to refer to the line from Shakespeare's The Life and Death of King John (Act 3, scene 4, 11. 8-9): "life is as tedious as a twice-told tale, / Vexing the dull ear of a drowsy man." This suggests the tedium of isolation many are experiencing due to pandemic-imposed social distancing, and alludes to the fact that we met and told each other our stories of queer isolation before deciding to re- 
tell them in this paper.

3. Led by Fern Pellerin whose work can be seen at: https://fernpellerin.wixsite.com/artist. Accessed 30 Jan 2021.

4. The first adoption of "queer" as a positive self-label is attributed to the group Queer Nation, founded in the early 1990s to combat violence against homosexuals. It was an offshoot of ACT UP (AIDS coalition to Unleash Power), founded in 1987 to demand more action to solve the AIDS crisis (Perlman, 2019).

5. Collins (2009/2000) creates a new kind of theory in this work, extending the concept of 'intellectual work' to include the centering experiences of one's own life as well as engagement in coalitions with others (xi) and contending that, though group histories are relational (266), coalitions with some groups are impossible because "while group experiences are interdependent, they are not equivalent" (267). She claims that despite varying distributions of privilege and oppression across marginalized groups, dialogues across "multiple angles of vision that accompany multiple group standpoints" promise new directions for "transversal politics" (268). Though being Black and being queer have different histories and geneologies, the experiences of those so categorized share relational positions vis à vis their respective subordination to hegemony. As Barbara Smith $(1982,171)$ points out, the intersecting nature of oppressions do not produce absolute oppressors or pure victims.

6. Leslie Stephen (1832-1904) literary critic, editor, and father of Virginia Woolf and Vanessa Bell, wrote three volumes called Hours in a Library (1879) for The Cornhill Magazine, which distinguished him as one of the first serious critics of the novel. See https://www.britannica.com/biography/Leslie-Stephen. Writing about the relationship between poetry and philosophy, a relation we take to be central to a judicious balance of story and analysis, Stephen says, "All that can safely be said is that a man's thoughts, whether embodied in symbols or worked out in syllogisms, are more valuable in proportion as they indicate greater philosophical insight; and therefore that, ceteris paribus, that man is the greater poet whose imagination is most transfused with reason; who has the deepest truths to proclaim as well as the strongest feelings to utter" (Stephen 1879,180).

7. For example, philosophers of education, such as Greene (1978), VanManen (1989), and Roland Martin
(1992), broke with traditional concepts of curriculum in the last decades of the 20th century, as did curriculum theorists Grumet (1978), Schubert (1986), and Pinar \& Reynolds (1991).

8. See Davis and Heilbroner, 2010 and Gilbert, 2011.

9. The term "defamiliarization" is a translation from the Russian term ostranenyia coined by Viktor Shklovsky $(1990 / 1929)$ to refer to the role of art as a device for making the "stone stonier."

10. "Merch" is an informal abbreviation for "merchandise" marketed to a particular fan base. In this case the fanbase is that of RuPaul, a drag queen TV personality who is known for bringing the lives of LGBTQ+ people to mainstream media. For episodes of RuPaul's Drag Race see https://www.crave.ca/en/tv-shows/rupauls-dragrace.

11. Nova Scotia did not have high infection rates during the first and second waves and collaborated with nearby provinces to put in place an Atlantic bubble to allow for travel. Of the 65 deaths in the first wave, tragically 53 were elders in Nova Scotia's largest long-term care facility in Halifax where the virus spread before it was understood the extent of infection control needed to protect against COVID-19. See McPhee, 2021, accessed on 15 Mar. 2021 at https://www.thechronicleherald.ca/news/ local/northwood-halifax-had-53-deaths-when-pandemicstarted-heres-how-theyve-changed-546700/. At the time of initial submission in April 2021, one more death from COVID-19 had occurred, a woman over 80 years of age. As of July 12, 2021, Nova Scotia has weathered a third wave, bringing the total COVID fatalities to 92 . See Government of Nova Scotia, accessed on 12 July 2021 at https://novascotia.ca/coronavirus/data/. The population of the province as of the second quarter of 2021 is 982 , 326. See Statistics Canada, accessed on 12 July 2021 at https://www150.statcan.gc.ca/t1/tbl1/en/tv.action? pid $=1710000901$

\section{Works Cited}

Arendt, Hannah. 1973/1951. The Origins of Totalitarianism (1951). New York: Harcourt Brace Jovanovich.

Austin, Ashley, and Revital Goodman. 2017. "The impact of social connectedness and internalized transphobic stigma on self-esteem among transgender and gender non-conforming adults." Journal of Homosexuality 64, 
no. 6: 825-841.

DOI:10.1080/00918369.2016.1236587

Austin-Smith, Brenda. 2020. President's Message. Canadian Association of University Teachers Bulletin, December-January. Accessed on 30 December 2020 at https:// www.caut.ca/bulletin

Baum, Frank L. 2010/1900. The Wonderful Wizard of $O z$. Oxford University Press.

Blinn, Daniel, and Sue McKay. 2020. "Safe Spaces for Queer Teachers." The Teacher (April) 58 no. 6, 6. Halifax: Nova Scotia Teachers Union.

Britzman, Deborah P. 1998. Lost Subjects, Contested Objects: Toward a Psychoanalytic Inquiry of Learning. New York: State University of New York.

Britzman, Deborah P. 1995. "Is There a Queer Pedagogy? Or, Stop Reading Straight.” Educational Theory 45, no. 2: 152-165.

Brown, Rosemary. 1989. Being Brown: A Very Public Life. Toronto: Random House.

Cambridge Dictionary. 2021. "Interpellate." Accessed on 20 March 2021 at https://dictionary.cambridge.org/dictionary/english/interpellate

Chen, Yilin, and Thomas Hugh Feeley. 2013. "Social support, social strain, loneliness, and well-being among older adults: An analysis of the Health and Retirement Study." Journal of Social and Personal Relationships, 31, no. 2: 141-161. DOI: 10.1177/0265407513488728

Collins, Patricia Hill. 2009/2000. Black Feminist Thought. Knowledge, Consciousness, and the Politics of Empowerment. New York and London: Routledge.

Danon, Leon, Lucas Labasa, and Ellen Brooks-Pollock. 2021 "Household bubbles and COVID-19 transmission: insights from percolation theory." Philosophical Transactions of the Royal Society B 376, no. 1829: 20200284. https://doi.org/10.1098/rstb.2020.0284

Davis, Kate, and David Heilbroner (dir., prod.) 2010. "Stonewall Uprising: A Film Documentary." PBS/The American Experience, 82 mins. http://www.pbs.org/ wgbh/americanexperience/films/stonewall/

DePalma, Renée. 2020. "Queer Pedagogy as an Impossible Profession.” In Oxford Research Encyclopedia of Education. https://doi.org/10.1093/acrefore/

9780190264093.013 .1360
Drabble, Laurie A., and Michele J. Eliason. 2021. "Introduction to Special Issue: Impacts of the COVID-19 Pandemic on LGBTQ+ Health and Well-Being." Journal of Homosexuality 68, no. 4: 545-559. DOI:

10.1080/00918369.2020.1868182

Fetner, Tina, Athena Elafros, Sandra Bortolin, and Coralee Drechsler. 2012. "Safe spaces: Gay-straight alliances in high schools." Canadian Review of Sociology/Revue Canadienne de Sociologie 49, no. 2: 188-207.

Fish, Jessica N., Lauren B. McInroy, Megan S. Paceley, Natasha D. Williams, Sara Henderson, Deborah S. Levine, and Rachel N. Edsall. 2020. "I'm Kinda Stuck at Home With Unsupportive Parents Right Now":

LGBTQ Youths' Experiences with COVID-19 and the Importance of Online Support. Journal of Adolescent Health 67 no. 3, 450-452. https://doi.org/10.1016/j.jadohealth.2020.06.002

Forrest, Michelle. 2001. "The Role of Difficult Artworks in Teaching to be Critical." Philosophical Inquiry in Education 14, no. 2: 39-58.

Friedan, Betty. 1963. The Feminine Mystique. London: Gollancz.

Freire, Paulo. 1974/1968. Pedagogy of the Oppressed. New York: Continuum.

Garcia, Jonathan, Nancy Vargas, Jesse L. Clark, Mario Magaña Álvarez, Devynne A. Nelons, and Richard G. Parker. 2020. "Social Isolation and Connectedness as Determinants of Well-being: Global Evidence Mapping Focused on LGBTQ Youth." Global Public Health 15, no. 4: 497-519. DOI:

$10.1080 / 17441692.2019 .1682028$

Gilbert, James. 2011. (review). Journal of American History 98, no. 3: 936-939. https://doi.org/10.1093/jahist/ jar467

Greene, Maxine. 1978. Landscapes of Learning. New York: Teachers College Press.

Grumet, Madeleine. 1978. "Curriculum as Theatre: Merely Players.” Curriculum Inquiry 8, no. 1: 37-64.

Holman Jones, Stacy, and Tony E. Adams. 2016. "Autoethnography is a Queer Method.” In Queer Methods and Methodologies: Intersecting Queer Theories and Social Science Research by Kath Browne \& Catherine J. Nash, 195214. London and New York: Routledge. 
House, James S. 2001. "Social Isolation Kills, But How and Why?" Psychosomatic Medicine 63, no. 2: 273-274.

Joy, Phillip, Stéphanie EM Gauvin, Megan Aston, and Matthew Numer. 2020. "Reflections in Comics: The Views of Queer Artists in Producing Body Image Comics and How Their Work Can Improve Health." Journal of Graphic Novels and Comics :1-27. https://doi.org/ 10.1080/21504857.2020.1806891

Lalich, Janja, and Karla McLaren. 2010. "Inside and Outcast: Multifaceted Stigma and Redemption in the Lives of Gay and Lesbian Jehovah's Witnesses." Journal of Homosexuality 57, no. 10: 1303-1333. DOI: 10.1080/00918369.2010.517076

Lapointe, Alicia A. 2016. "Queering the Social Studies: Lessons to be Learned from Canadian Secondary School Gay-straight Alliances." The Journal of Social Studies Research 40, no. 3: 205-215. https://doi.org/10.1016/ j.jssr.2015.07.004

Martin, Jane Roland. 1992. The Schoolhome: Rethinking Schools for Changing Families. Cambridge Mass: Harvard University Press.

McPhee, John. 2021. "Northwood Halifax had 53 Deaths When Pandemic Started. Here's How They've Changed." Halifax: The Chronicle-Herald, January, 29, 2021.

Neto, Jo-ao Nemi. 2018. "Queer Pedagogy: Approaches to Inclusive Teaching." Policy Futures in Education 16, no. 5: 589-604.

Oxford English Dictionary. 2021. "Queer." Oxford: Oxford University Press. Accessed on 3 Feb 2021 at https://www.oxfordlearnersdictionaries.com/definition/ english/queer_1

Perlman, Merrill. 2019. "How the Word 'Queer' was Adopted by the LGBTQ Community." Columbia Journalism Review. 22 January. Accessed on 22 Feb 2021 at https://www.cjr.org/language corner/queer.php

Perone, Angela K., Berit Ingersoll-Dayton, and Keisha Watkins-Dukhie. 2020. "Social Isolation Loneliness among LGBT Older Adults: Lessons Learned from a Pilot Friendly Caller Program." Clinical Social Work Journal 48, no. 1: 126-139. https://doi.org/10.1007/ $\underline{\text { s10615-019-00738-8 }}$

Pinar, William \& W. M. Reynolds (Eds.) 1991. Understanding Curriculum as Phenomenological and Deconstructed Texts. New York: Teachers College Press.
Pollock, Della. 2007. "The Performative 'I'”. Cultural Studies Critical Methodologies 7, no. 3: 239-55. DOI: $10.1177 / 1532708606288649$

Pollock, Della. 1998. "Performing Writing." In The Ends of Performance, edited by Peggy Phelan and Jill Lane, 73103. New York: NYU Press.

Ratanashevorn, Rattanakorn and Emily C. Brown. 2021. "Alone in the Rain(bow): Existential Therapy for Loneliness in LGBTQ + Clients." Journal of LGBTQ Issues in Counseling 15, no. 1: 110-127, DOI:

10.1080/15538605.2021.1868375

Ricco, John Paul. 2020. "Isolation, Loneliness, Solitude: The COVID-19 Pandemic Has Brought Us Too Close Together." Topia: Canadian Journal of Cultural Studies 41: 164-172.

Salerno, John P., Jackson Devadas, M. Pease, Bryanna Nketia, and Jessica N. Fish. 2020. "Sexual and Gender Minority Stress Amid the COVID-19 Pandemic: Implications for LGBTQ Young Persons' Mental Health and Well-Being." Public Health Reports 135, no. 6: 721-727. https://doi.org/10.1177/0033354920954511

Shklovsky, Viktor. 1990/1929. The Theory of Prose (1929). 2nd ed. Translated by Sher, Benjamin. Elmwood Park: Dalkey Archive.

Schubert, William H. 1986. Curriculum: Perspective, Paradigm, and Possibility. New York: Macmillan.

Sedgwick, Eve Kosofsky. 1993. Tendencies. Durham: Duke University Press.

Smith, Barbara. 1982. "Toward a Black Feminist Criticism.” In But Some of Us Are Brave, edited by Gloria T. Hall, Patricia Bell Scott, and Barbara Smith. Old Westbury, NY: Feminist Press.

Spry, Tami. 2016. Autoethnography and the Other: Unsettling Power through Utopian Performatives. New York: Routledge.

Stephen, Leslie. 1879. Hours in a Library. London: Cornhill Magazine.

VanManen, Max 1989. Researching Lived Experience. London, ON: Althouse Press.

Warren, John T. 2006. "Introduction: Performance Ethnography: A TPQ Symposium.” Text and Performance Quarterly 26, no. 4: 317-319. 
Wright, Julia, R.M. Kennedy, Kate Cushon, Nicole Picton, Jean Portugais, Momin Rahman. 2020. "Perspectives on the Pandemic and PSE." CAUT Bulletin, December-January. Ottawa: Canadian Association of University Teachers. Accessed on 27 March 2021 at https://www.caut.ca/bulletin/2020/12/perspectives-pandemic-and-pse

Yalom, Irvin. 1980. Existential Psychotherapy. Basic Books.

Yalom, Irvin and Ruthellen Josselson. 2014. "Existential Psychotherapy." In Current Psychotherapies (10th ed.), edited by In Danny Wedding and Raymond Corsini. Brooks/Cole.

Yang, Jie, Yoosun Chu, and Mary Anne Salmon. 2018. "Predicting Perceived Isolation among Midlife and Older LGBT Adults: The Role of Welcoming Aging Service Providers." The Gerontologist 58, no. 5: 904-912. https://doi.org/10.1093/geront/gnx092

Youdell, Deborah. 2010. "Queer Outings: Uncomfortable Stories about the Subjects of Post-structural School Ethnography." International Journal of Qualitative Studies in Education 23, no. 1: 87-100. DOI:

10.1080/09518390903447168 